\section{MECHANICAL RESPONSE OF KNEE MUSCLES IN HIGH LEVEL BODYBOARDERS DURING PERFORMANCE}

\author{
RESPOSTAS MECÂNICAS DA MUSCULATURA DO JOELHO DE BODYBOARDERS \\ DE ALTO NIVIEL DURANTE O DESEMPENHO
}

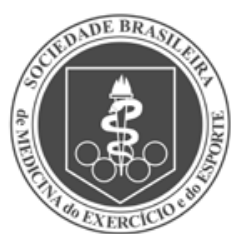

Artigo Original ORIGINAL ARTICLE Artículo Original

\author{
RESPUESTA MECÁNICA DE LA MUSCULATURA DE LA RODILLA EN BODYBOARDERS \\ DE ALTO NIVEL DURANTE EL DESEMPEÑO
}

\author{
Dario Rodríguez-Matoso' \\ (Physical Educator) \\ Alejandro Mantecón ${ }^{1}$ \\ (Physical Educator) \\ Eduardo Barbosa-Almeida' \\ (Physical Educator) \\ Teresa Valverde ${ }^{2}$ \\ (Physical Educator) \\ Juan Manuel García-Manso \\ (Physical Educator) \\ David Rodríguez-Ruiz \\ (Physical Educator)

\begin{abstract}
1. Department of Physical Education, University of Las Palmas de Gran Canaria, Spain.

2. Faculty of Physical Activity and Sports Science from Catholic University of Valencia, Spain.
\end{abstract}

\section{Correspondência:}

Campus Universitario de Tafira, s/n Edificio de Ciencias de la Actividad Física y el Deporte. 35017. Las Palmas de Gran Canaria. Spain. drodriguez@def.ulpgc.es

\begin{abstract}
Introduction: bodyboarding is a kind of surfing that has been growing very rapidly over the last decade and has now developed into one of the fastest growing water sports in the world. Objectives: evaluate the effects of fatigue on rectus femoris (RF), vastus lateralis (VL) and vastus medialis (VM) and biceps femoris (BF) and semitendinosus (ST) during a high-level bodyboard competition using tensiomyography (TMG). Methods: subjects were 11 highly experienced (years of practice: 15, SD=4.65) male bodyboarders (age: $28.17, \mathrm{SD}=2.89$, body weight: $74.83, \mathrm{SD}=6.13 \mathrm{~kg}$; height: $179.25, \mathrm{SD}=3.93 \mathrm{~cm} ; \mathrm{BMl}: 23.29, \mathrm{SD}=1.81$ ) participating in the final of the 2010 Spanish championship. Results: the fatigue is especially evident due to a decrease in the values of relaxation time (Tr) and sustain time (Ts) caused by the specific characteristics of waves, how the waves evolve and the type of manoeuvre executed in competition due to the wave characteristics. The maximum radial displacement (Dm) value increased slightly in all muscles analysed and normalised response speed (Vrn) was stable, with a tendency to improve as athletes adapted to the type of physical effort and the environmental conditions of the competition. Conclusions: the study shows that the fatigue in the extensor and flexor muscles of the knee occurs in response to the demands of competition.
\end{abstract}

Keywords: sports, muscle fatigue, muscle strength dynamometer, myography.

\section{RESUMO}

Introdução: bodyboarding é uma modalidade do surfe que vem crescendo rapidamente nas últimas décadas e atualmente é um dos esportes aquáticos que mais cresce no mundo. Objetivo: avaliar o efeito da fadiga nos músculos reto femoral (RF), vasto lateral (VL), vasto medial (VM), biceps femoral (BF) e semitendíneo (ST) durante competição de alto nível através da tensiomiografia (TMG). Métodos: a amostra foi composta por 11 bodyboarders de alto nível (anos de prática: 15, $D P=4,65$, idade: $28,17, D P=2,89$ anos, peso: $74,83, D P=6,13 \mathrm{~kg}$; estatura: $179,25, D P=3,93 \mathrm{~cm} ; I M C: 23,29, D P=1,81$ ), participantes da final do Campeonato Espanhol de 2010. Resultados: a fadiga é evidente devido a uma diminuição dos valores de tempo de relaxamento (Tr) e tempo de sustentação (TS), que pode ser causada pelas características das ondas, de como elas se comportam e ao tipo de manobras realizadas em competição. Os valores de deslocamento radial máximo (Dm) aumentaram em todos os músculos analisados e a velocidade de resposta normalizada foi estável, com uma leve tendência à melhora conforme os atletas se adaptam ao tipo de esforço físico e às condições ambientais da competição. Conclusão: observou-se fadiga da musculatura flexora e extensora do joelho em repostas às demandas da competição.

Palavras-chave: esportes, fadiga muscular, dinamômetro de força muscular, miografia.

\section{RESUMEN}

Introducción: el bodyboard es una modalidad del surf que viene creciendo rápidamente en las últimas décadas y actualmente es uno de los deportes acuáticos que más crece en el mundo. Objetivos: evaluar los efectos de la fatiga en los músculos: recto femoral (RF), vasto lateral (VL), vasto medial (VM), bíceps femoral (BF) y semitendinoso (ST) durante una competición de alto nivel mediante la tensiomiografia (TMG). Métodos: la muestra estaba compuesta por 11 bodyboarders de alto nivel (años de práctica: 15, DE =4,65, edad: 28,17, DE =2,89, peso: 74.83, DE =6,13 kg; altura: 179,25, DE =3,93 cm; IMC: 23,29, DE = 1,81), participantes en la final del Campeonato de España de 2010. Resultados: la fatiga es evidente debido a una disminución de los valores del tiempo de relajación (Tr) y tiempo de sustentación (TS), que puede ser causada por las características de las olas, de como éstas se comportan y al tipo de maniobras realizadas durante la competición. Los valores de desplazamiento máximo radial (Dm) aumentaron en todos los músculos analizados y la velocidad de respuesta normalizada (Vrn) se muestra estable, con tendencia a mejorar, debido a la adaptación de los deportistas al tipo de esfuerzo y a las condiciones ambientales en que se desarrolla la competición. Conclusión: el estudio muestra que la fatiga en los músculos extensores y flexores de la rodilla se produce en respuesta a las exigencias propias de la competición.

Palabras clave: deportes, fatiga muscular, dinamómetro de fuerza muscular, miografía. 


\section{INTRODUCTION}

Bodyboarding is a surfing discipline which has developed rapidly in the last 10 years and is now considered one of the world's fastest-growing water sports. As a result, events are becoming increasingly competitive and demanding and bodyboarders need to spend more time on training to improve, including training out of the water.

Because bodyboarding is a relatively new sport, little has been written about the fitness, physiological, biomechanical and psychological demands involved. Moreover, as with all sports in the sea, competitions are continually held at different locations. Waves have various characteristics, mostly due to environmental conditions ${ }^{1-2}$, which makes it difficult to develop and define standards for physical and psychological aspects of scientific research into sports disciplines of this kind.

All wave-riding sports normally have two separate phases with differentiated physical demands: paddling (arms and legs, in bodyboarding), and technical moves when riding the wave ${ }^{3-6}$. The psychological demand during the stationary phase, when the bodyboarder is preparing for the next wave position, is $40 \%$ of performance ${ }^{5,6}$. Other factors include heat time, competition tactics, body position on the board and specific bodyboarding features, such as the board ${ }^{7}$. Judging criteria are based on technical actions, performance and coincident timing accuracy $5,8,9$.

High-level sports competition requires knowledge and understanding to plan training loads. The most important aspect is how specific fatigue affects athlete performance. This determines changes in the muscular and neuromuscular structures, altering their rigidity, stimulus velocity condition and contraction speed ${ }^{10-11}$.

This study used Tensiomyography (TMG) to assess the effects of fatigue on knee extensor (rectus femoris, vastus lateralis and vastus medialis) and flexor muscles (biceps femoris and semitendinosus) during high-level bodyboard competition, analysing pre- and post-competition muscular response to 20-minute heats.

\section{METHODS}

Eleven highly experienced (Years of practice: 15, SD=4.65) male body boarders (Age: 28.17, SD=2.89, Body Weight: 74.83, SD=6.13kg; Height: 179.25, SD=3.93cm; BMl: 23.29, SD=1.81) participating in the final of the 2010 Spanish championship, in El Agujero (Gran Canaria, Canary Islands), volunteered to take part in the study. Following the Declaration of Helsinki for research involving human subjects, written informed consent was obtained from all subjects before the study, after they had received a full explanation about the nature of the procedures and possible associated risks.

Competition consisted of 20-minute heats. Best scores were obtained when performing on the 10 best waves. The structure comprised eighth-finals, quarter-finals, semi-finals and final. Sample data was collected on the same day, during the first part of competition (eighth-finals), held under the following environmental conditions (table 1):

Table 1. Environmental characteristics of competition.

\begin{tabular}{c|c}
\hline Environmental characteristic & Range \\
\hline Air temperature & $19-21^{\circ} \mathrm{C}$ \\
\hline Water temperature & $18-21^{\circ} \mathrm{C}$ \\
\hline Wave size & $1-11 / 2$ meters \\
\hline Wave length & 6 to 9 seconds \\
\hline Wave direction & Right \\
\hline Distance paddling & 20 minutes \\
\hline Heat length &
\end{tabular}

\section{MATERIALS}

Muscular response was assessed by TMG. This technique consists of placing a pressure sensor perpendicularly above the muscle belly studied ${ }^{12}$, following the manufacturer's recommendations ${ }^{13,14}$. To trigger contraction, incremental intensities of bipolar electric current (110 mA) are applied for one millisecond via two electrodes located at the proximal and distal ends of the muscle, without affecting the insertion tendons ${ }^{15,16}$. An interval is required between stimuli to avoid post-tetanic activation ${ }^{16-18}$.

TMG measures muscle belly radial displacement during contraction induced by an external electrical stimulus under isometric conditions. Five parameters were obtained from radial displacement of transverse muscle fibre: maximum muscle belly radial displacement (Dm), contraction time (Tc), sustain time (Ts), relaxation time ( $\mathrm{Tr}$ ) and normalised response speed ( $V r n)$. The reproducibility of this method and the validity of TMG experiment procedure have been assessed in several studies ${ }^{16,17,19-23}$.

TMG muscle response assessment was applied to extensor and flexor muscles. Extensor muscles were: Rectus Femoris (RF), Vastus Lateralis (VL), and Vastus Medialis (VM). Flexor muscles were: Biceps Femoris (BF) and Semitendinosus (ST). The procedure comprised two moments: firstly, before warming-up and entering the water; and secondly, immediately after performance. To ensure the same muscle segment was being assessed during both moments, the area was marked with a waterproof pen.

\section{Statistical analysis}

The descriptive statistics used were the mean and standard deviation. To compare Tensiomyography data results before and after performance, a t-student test was applied after conducting a normality test (Shapiro-Wilk). Statistical significance was set at $p<0.05$. Effect Size (es) was calculated using Glass's Delta ${ }^{24}$.

\section{RESULTS}

After performance, a decrease in sustain time (Ts) was observed in $R F, V L, V M$ and ST in both legs (table 2). Decrease in VL was statistically significant in the right leg $(p=0.05$; es $=-0.42)$ and ST showed a significant difference in the right leg $(p=0.013$; es $=-0.76)$ and the left leg $(p=0.015$; es= - 0.85).

In relaxation time $(\mathrm{Tr})$, a decrease was observed in extensor muscles in the right leg VM ( $p=0.021$; es $=-0.46)$, although this did not occur in knee joint flexor muscles (table 3).

Maximum radial displacement (Dm) and normalised response speed (Vrn) of the muscles analysed increased after performance, although Dm showed no statistical differences (table 4). In Vrn (table 5), statistical differences were shown in RF in the right leg ( $p=0.030$; es=0.86) and ST in the left leg ( $p=0.002$; es=1.32).

Table 2. Means, standard deviations, difference and effect size of sustain time (TS) in milliseconds for knee extensor (RF, VL and VM) and flexor muscles (BF and ST) evaluated before and after the heat.

\begin{tabular}{c|c|c|c|c|c|c}
\hline \multirow{2}{*}{ Ts (ms) } & \multicolumn{3}{|c|}{ Right leg } & \multicolumn{3}{c}{ Left leg } \\
\cline { 2 - 7 } & Pre & Post & $\mathbf{p ~ ( E S )}$ & Pre & Post & $\boldsymbol{p}$ (ES) \\
\hline \multirow{2}{*}{ Rectus femoris } & $\begin{array}{c}133.5 \\
( \pm 58.1)\end{array}$ & $\begin{array}{c}95.3 \\
( \pm 32.9)\end{array}$ & $\begin{array}{c}0.067 \\
(-0.66)\end{array}$ & $\begin{array}{c}106.6 \\
( \pm 55.7)\end{array}$ & $\begin{array}{c}79.5 \\
( \pm 39.7)\end{array}$ & $\begin{array}{c}0.213 \\
(-0.79)\end{array}$ \\
\hline \multirow{2}{*}{ Vastus lateralis } & $\begin{array}{c}107.7 \\
( \pm 79.3)\end{array}$ & $\begin{array}{c}77.5 \\
( \pm 67.4)\end{array}$ & $\begin{array}{c}0.248 \\
(-0.38)\end{array}$ & $\begin{array}{c}87.4 \\
( \pm 44.4)\end{array}$ & $\begin{array}{c}68.9 \\
( \pm 44.4)\end{array}$ & $\begin{array}{c}0.050^{*} \\
(-0.42)\end{array}$ \\
\hline \multirow{2}{*}{ Vastus medialis } & 175.8 & 169.8 & 0.374 & 189.3 & 203.2 & 0.859 \\
& $( \pm 27.7)$ & $( \pm 39.9)$ & $(-0.10)$ & $( \pm 27.7)$ & $( \pm 66.2)$ & $(0.50)$ \\
\hline \multirow{2}{*}{ Biceps femoris } & 207.1 & 206.7 & 0.929 & 199.0 & 197.1 & 0.722 \\
& $( \pm 72.5)$ & $( \pm 57.9)$ & $(-0.01)$ & $( \pm 61.8)$ & $( \pm 66.9)$ & $(-0.03)$ \\
\hline \multirow{2}{*}{ Semitendinosus } & 191.7 & 144.5 & $0.013^{*}$ & 161.7 & 140.5 & $0.015^{*}$ \\
& $( \pm 61.6)$ & $( \pm 20.1)$ & $(-0.76)$ & $( \pm 24.8)$ & $( \pm 13.9)$ & $(-0.85)$ \\
\hline * $p \leq 0.05$.
\end{tabular}


Table 3. Means, standard deviations, difference and effect size of relaxation time ( $\mathrm{Tr}$ ) in milliseconds for knee extensor (RF, VL and VM) and flexor muscles (BF and ST) evaluated before and after the heat.

\begin{tabular}{|c|c|c|c|c|c|c|}
\hline \multirow{2}{*}{$\operatorname{Tr}(\mathrm{ms})$} & \multicolumn{3}{|c|}{ Right leg } & \multicolumn{3}{|c|}{ Left leg } \\
\hline & Pre & Post & $p(E S)$ & Pre & Post & $p$ (ES) \\
\hline Rectus femoris & $\begin{array}{c}91.8 \\
( \pm 57.5) \\
\end{array}$ & $\begin{array}{c}55.3 \\
( \pm 28.8) \\
\end{array}$ & $\begin{array}{c}0.067 \\
(-0.63) \\
\end{array}$ & $\begin{array}{c}67.4 \\
( \pm 52.8) \\
\end{array}$ & $\begin{array}{c}43.6 \\
( \pm 37.1) \\
\end{array}$ & $\begin{array}{c}0.286 \\
(-0.45) \\
\end{array}$ \\
\hline Vastus lateralis & $\begin{array}{c}73.5 \\
( \pm 72.8) \\
\end{array}$ & $\begin{array}{c}47.7 \\
( \pm 61.4) \\
\end{array}$ & $\begin{array}{c}0.248 \\
(-0.35) \\
\end{array}$ & $\begin{array}{c}55.5 \\
( \pm 43.5)\end{array}$ & $\begin{array}{c}39.2 \\
( \pm 39.8) \\
\end{array}$ & $\begin{array}{r}0.110 \\
(-0.37) \\
\end{array}$ \\
\hline Vastus medialis & $\begin{array}{c}67.7 \\
( \pm 50.7) \\
\end{array}$ & $\begin{array}{c}44.5 \\
(34.2) \\
\end{array}$ & $\begin{array}{l}0.021 * \\
(-0.46) \\
\end{array}$ & $\begin{array}{c}67.3 \\
( \pm 45.7) \\
\end{array}$ & $\begin{array}{c}81.7 \\
( \pm 75.4) \\
\end{array}$ & $\begin{array}{l}0.594 \\
(0.31) \\
\end{array}$ \\
\hline Biceps femoris & $\begin{array}{c}69.9 \\
( \pm 41.3)\end{array}$ & $\begin{array}{c}66.4 \\
( \pm 48.3)\end{array}$ & $\begin{array}{c}0.861 \\
(-0.09)\end{array}$ & $\begin{array}{c}73.8 \\
( \pm 34.9)\end{array}$ & $\begin{array}{c}72.5 \\
( \pm 50.3)\end{array}$ & $\begin{array}{c}0.657 \\
(-0.04)\end{array}$ \\
\hline Semitendinosus & $\begin{array}{c}56.5 \\
( \pm 30.3)\end{array}$ & $\begin{array}{c}61.1 \\
( \pm 30.3)\end{array}$ & $\begin{array}{l}0.859 \\
(0.15)\end{array}$ & $\begin{array}{c}62.2 \\
( \pm 23.3)\end{array}$ & $\begin{array}{c}60.5 \\
( \pm 24.2)\end{array}$ & $\begin{array}{l}0.807 \\
(-0.07)\end{array}$ \\
\hline
\end{tabular}

Table 4. Means, standard deviations, difference and effect size of maximum radial displacement (Dm) in milliseconds for knee extensor (RF, VL and VM) and flexor muscles (BF and ST) evaluated before and after the heat.

\begin{tabular}{c|c|c|c|c|c|c}
\hline \multirow{2}{*}{ Dm (ms) } & \multicolumn{3}{|c|}{ Right leg } & \multicolumn{3}{c}{ Left leg } \\
\cline { 2 - 7 } & Pre & Post & $\boldsymbol{p}$ (ES) & Pre & Post & $\boldsymbol{p}$ (ES) \\
\hline \multirow{2}{*}{ Rectus femoris } & $\begin{array}{c}8.5 \\
( \pm 2.2)\end{array}$ & $\begin{array}{c}8.6 \\
( \pm 1.6)\end{array}$ & $\begin{array}{c}0.891 \\
(0.05)\end{array}$ & $\begin{array}{c}7.4 \\
( \pm 2.4)\end{array}$ & $\begin{array}{c}8.2 \\
( \pm 1.5)\end{array}$ & $\begin{array}{c}0.338 \\
(0.32)\end{array}$ \\
\hline \multirow{2}{*}{ Vastus lateralis } & 4.7 & 5.2 & 0.274 & 5.3 & 5.4 & 0.863 \\
& $( \pm 1.4)$ & $( \pm 1.6)$ & $(0.36)$ & $( \pm 1.6)$ & $( \pm 1.2)$ & $(0.05)$ \\
\hline \multirow{2}{*}{ Vastus medialis } & 6.7 & 7.9 & 0.075 & 6.8 & 7.8 & 0.052 \\
& $( \pm 2.1)$ & $( \pm 1.2)$ & $(0.55)$ & $( \pm 1.6)$ & $( \pm 1.5)$ & $(0.60)$ \\
\hline \multirow{2}{*}{ Biceps femoris } & 4.8 & 4.2 & 0.589 & 6.6 & 6.6 & 0.957 \\
& $( \pm 2.3)$ & $( \pm 1.8)$ & $(-0.22)$ & $( \pm 2.5)$ & $( \pm 2.1)$ & $(0.02)$ \\
\hline \multirow{2}{*}{ Semitendinosus } & 7.2 & 8.1 & 0.219 & 9.2 & 9.5 & 0.722 \\
& $( \pm 2.5)$ & $( \pm 1.6)$ & $(0.35)$ & $( \pm 3.5)$ & $( \pm 2.1)$ & $(0.07)$ \\
\hline
\end{tabular}

Table 5. Means, standard deviations, difference and effect size of Normalised Response Speed ( $V r n)$ in milliseconds for knee extensor (RF, VL and VM) and flexor muscles (BF and ST) evaluated before and after the heat.

\begin{tabular}{c|c|c|c|c|c|c}
\hline \multirow{2}{*}{ Vrn (ms) } & \multicolumn{3}{|c|}{ Right leg } & \multicolumn{3}{c}{ Left leg } \\
\cline { 2 - 7 } & Pre & Post & $\mathbf{p ~ ( E S )}$ & Pre & Post & $\boldsymbol{p}($ ES) \\
\hline \multirow{2}{*}{ Rectus femoris } & $\begin{array}{c}24.3 \\
( \pm 3.2)\end{array}$ & $\begin{array}{c}27.0 \\
( \pm 3.8)\end{array}$ & $\begin{array}{c}0.030^{*} \\
(0.86)\end{array}$ & $\begin{array}{c}24.1 \\
( \pm 4.2)\end{array}$ & $\begin{array}{c}24.7 \\
( \pm 3.6)\end{array}$ & $\begin{array}{c}0.525 \\
(0.14)\end{array}$ \\
\hline \multirow{2}{*}{ Vastus lateralis } & $\begin{array}{c}29.4 \\
( \pm 4.1)\end{array}$ & $\begin{array}{c}31.9 \\
( \pm 4.4)\end{array}$ & $\begin{array}{c}0.083 \\
(0.60)\end{array}$ & $\begin{array}{c}31.6 \\
( \pm 1.9)\end{array}$ & $\begin{array}{c}32.2 \\
( \pm 4.5)\end{array}$ & 0.347 \\
& 30.1 & 31.8 & 0.296 & 28.5 & 30.5 & 0.127 \\
\hline \multirow{2}{*}{ Vastus medialis } & $( \pm 5.8)$ & $( \pm 2.4)$ & $(0.31)$ & $( \pm 5.4)$ & $( \pm 4.5)$ & $(0.37)$ \\
\hline \multirow{2}{*}{ Biceps femoris } & 30.6 & 35.8 & 0.295 & 22.4 & 24.6 & 0.278 \\
& $( \pm 10.8)$ & $( \pm 11.1)$ & $(0.48)$ & $( \pm 7.4)$ & $( \pm 7.4)$ & $(0.30)$ \\
\hline \multirow{2}{*}{ Semitendinosus } & 20.6 & 18.8 & 0.239 & 17.1 & 20.1 & $0.002 *$ \\
& $( \pm 4.5)$ & $( \pm 2.7)$ & $(-0.40)$ & $( \pm 2.2)$ & $( \pm 4.3)$ & $(1.32)$ \\
\hline
\end{tabular}

${ }^{*} p \leq 0.05$.

\section{DISCUSSION}

Bodyboarding is an intermittent sport with two clearly differentiated exercise phases in terms of technique (paddling and wave riding). Leg muscles are used both for movement during performance and when searching for the best waves.

Subjects showed changes in the response of knee joint flexors and extensors during performance. These alterations may have been caused by the acute fatigue observed in the active structures after performance. Repeated skeletal muscle activation causes functional impairment, which is manifested by muscle state alterations and neuromuscular response, altering muscle stiffness, stimulus conduction and contraction velocity ${ }^{10,11}$.

Bodyboarding competition is therefore characterised by sets that have high intensity and a short duration. When riders are over the wave, they set up a series of manoeuvres of varying complexity and radicalism, in what is called the wave moment. This is combined with long periods of less intensity, when riders paddle from the time the wave moment ends, searching for the best place to catch the next wave, in what is known as the paddling moment. The final moment, when riders wait for the next wave, has psychological requirements and fewer physiological demands.

During subsequent phases, the knee muscle extensors and flexors are constantly soliciting and responding to the intensity described above. However, this depends on the type of technical actions performed by the bodyboarder (rolling, $360^{\circ}$ spins, aerials, aerial reverse), as well as the paddling technique used (arms only, arms and kicking, kicking only).

In the study subjects, post-performance Ts and Tr were assessed in $R F, V L, V M, B F$ and $S T$. The changes showed statistically significant differences ( $p=0.05$, es=- 0.42$)$ in the right leg Ts for $V L$ and in both legs for ST (right: $p=0.013$; $e s=-0.76$; left: $p=0.015$; es=-0.85). Another statistically significant difference was observed in the right leg VM $\operatorname{Tr}(p=0.021$; es=- 0.46). These changes in $\operatorname{Tr}$ and Ts may be related to biochemical modifications of myoplasmic $\mathrm{Ca}^{2+25-27}$.

Another way of assessing muscle fatigue with TMG is through muscle stiffness. Dm shows how low values represent a high level of stiffness and high values represent a lower level of stiffness. As muscle potentiation increases, Dm values decrease as a result of fatigue. In this study, Dm values showed no apparent change. This could be interpreted as an initial stage of local fatigue due to performance, most obviously reflected in the $V M$ and $V L$ values of both legs (table 3 ). The asymmetry shown by these athletes in the knee flexor muscles is also worth noting.

The action of the hip flexor muscles (RF) depends on the body position on the board (lying prone in hyperextension, supported by the elbows and forearms) and the specific technical actions in competition (rolling, aerials, $360^{\circ}$ spins, etc.). These actions require the legs to be flexed 90 degrees so the fins can be taken out of the water to improve the move. This accentuates the load on the hip flexor muscles (RF), which is reflected in a decrease in $T$ s and $T r$.

However, it should be taken into consideration that most manoeuvres are performed with the legs crossed, which is manifested in the ST ( T) and VM ( $\mathrm{Tr}$ ) response in the right leg. This is because in competition, performance is on waves moving to the right, as bodyboarders are obliged to ride on this side for judging.

TMG has proven to be a technique that is sensitive both to morphological changes caused by sport- specific features and to muscle adaptations to technical actions and the position in the competition area ${ }^{28}$.

The present study shows how the muscles assessed present moderate improvement during final assessment, particularly in Vrn. This enhancement is statistically significant in RF of both legs (right leg: $p=0.030$, es $=0.86$; left leg $p=0.002$, es $=1.32$ ). The combination of various intensities and performance characteristics could explain why fatigue was not shown in this variable and did not have a negative effect on muscle contraction speed.

Cold is also an influential factor on Vm, as body heat decreases 30 times faster in water than at ambient temperature ${ }^{29}$. This becomes relevant in competition, because athletes spend a long time in cold water. Cold also affects muscle response speed when it is intense and prolonged $^{30}$. It must be taken into consideration that these athletes are highly experienced and highly capable of adapting to physical effort and water temperatures (18-220) of this kind.

Further research: These results open up several possibilities for further studies, such as examining the physiological impact in other types of waves and environmental conditions and analysing the workload and/or recovery in leg muscles during the paddling phase. Similarly, repetitions of techniques and the corresponding impact on fitness requirements could also be assessed. 
Practical Applications: Bodyboarding is an intermittent sport with two clearly differentiated exercise phases in terms of technique (paddling and wave riding). Leg muscles are important during both stages. However, the asymmetrical effort in the knee flexor and extensor muscles of both legs in these athletes must be taken into consideration.

Some of the influential factors in the hip flexor muscles (RF) are body position on the board (lying prone in hyperextension, supported by the elbows and forearms) and the performance of technical actions (rolling, aerials, $360^{\circ}$ spins, etc.), which require the legs to be flexed 90 degrees so the fins can be taken out of the water to improve the move. This accentuates the load on the hip flexor muscles (RF), which is reflected in a decrease in $T s$ and $T r$.

Cold is considered an environmental factor which adversely affects muscle speed response (Vrn) when it is intense and prolonged, as in the case of a bodyboarding competition.

TMG is considered to be a technique that has the sensitivity to assess both morphological changes caused by sport-specific features and muscle adaptations to technical actions and position in the competition area.

\section{CONCLUSIONS}

This study shows that performance causes fatigue in the knee extensor and flexor muscles. Fatigue is particularly evident in the decrease in $\mathrm{Tr}$ and Ts values, due to the specific characteristics of the waves, how the waves evolve and the type of manoeuvre executed during performance. Dm values increased slightly in all muscles analysed. Vrn remained stable, with a tendency to improve, because of the athletes' ability to adapt to the physical effort required and the environmental conditions of performance.

\section{ACKNOWLEDGEMENTS}

The authors are grateful to the Spanish Surfing Federation, the Canary Islands Surfing Federation and the bodyboarders who took part in this study.

All authors have declared there is not any potential conflict of interests concerning this article.

\section{REFERENCES}

1. Guisado R. The Art of Surfing a training manual for the developing and competitive surfer. Guilford, CT: Falcon; 2003.

2. Mendez-Villanueva A, Mujika I, Bishop D. Variability of competitive performance assessment of elite surfboard riders. J Strength Cond Res. 2010;24(1):135-9.

3. Meir RA, Lowdon BJ, Davie AJ. Heart rates and estimated energy expenditure during recreational surfing. Aust J Sci Med Sport. 1991;23:70-4.

4. Lowdon BJ, Lowdon M. Competitive surfing a dedicated approach. Victoria: Mouvement Publications; 1998.

5. Mendez-Villanueva A, Bishop D. Physiological aspects of surfboard riding performance. Sports Med. 2005;35(1):55-70

6. Mendez-Villanueva A, Perez-Landaluce J, Bishop D, Fernandez-Garcia F, Ortolano R, Leibar,X. et al Upper-body aerobic fitness comparison between two groups of competitive surfboard riders. J Sci Med Sport. 2005;8(1):43-51.

7. Gómez J, Sanmartín-Gil G, Chacón-Souto P, Gomez-Varela J. Obsesión por las olas. Madrid: Desnivel; 2000.

8. Lowdon BJ, Patrick J, Ross K. Manoeuvres used and judges' scores in an international surfing contest. Summary report. Belconnen, ACT: Australian Sports Commission; 1996.

9. Mendez-Villanueva A, Bishop D, Hamer P. Activity profile of world-class professional surfers during competition. J Strength Cond Res. 2006;20(3):477-82.

10. Westerblad H, Bruton JD, Allen DG, Lännergren J. Functional significance of Ca2+ in long-lasting fatigue of skeletal muscle. Eur J Appl Physiol. 2000;83(2-3):166-74.

11. Maclntosh BR, Rassier DE. What is fatigue? Can J Appl Physiol. 2002;27(1):42-55.

12. Valencic V, Knez N. Measuring of skeletal muscles' dynamic properties. Artif Organs. 1997;21(3):240-2.

13. Gorelick ML, Brown JM. Mechanomyographic assessment of contractile properties within seven segments of the human deltoid muscle. Eur J Appl Physiol. 2007;100(1):35-44..

14. Rodríguez-Matoso D, García-Manso JM, Sarmiento S, de Saa Y, Vaamonde D, Rodríguez-Ruiz D, et al. Evaluación de la respuesta muscular como herramienta de control en el campo de la actividad física, la salud y el deporte. Rev Andal Med Deporte. 2012;5(1):28-40.

15. Valencic V. Method for selective and non-invasive detection of skeletal muscles contraction process. International Application Published under the Patent Cooperation Treaty (PCT). No WO 02/074167 A1. 2002.

16. Simunic, B. Model of longitudinal contractions and transverse deformations in skeletal muscles [thesis]. Ljubljana: University of Ljubljana Faculty of Electrical Engineering; 2003.

17. Belic A, Knez N, Karba R, Valencic V. Validation of the human muscle model. In: Proceedings of the
2000 Summer Computer Simulation Conference. July 2000, Vancouver, British Columbia. Session 1 Issues on Whole Body Modeling, 2000. p. 16-20.

18. Rodríguez-Matoso D, Rodríguez-Ruiz D, Quiroga ME, Sarmiento S, De Saa Y, García-Manso JM. Tensiomiografía, utilidad y metodología en la evaluación muscular. Rev Int Med Cienc Activ Fís Deporte. 2010;10(40): 620-9.

19. Krizaj D, Simunic B, Zagar T. Short-term repeatability of parameters extracted from radial displacement of muscle belly. J Electromyogr Kinesiol. 2008;18(4):645-51.

20. Tous-Fajardo J, Moras G, Rodríguez-Jiménez S, Usach R, Doutres DM, Maffiuletti NA. Inter-rater reliability of muscle contractile property measurements using non-invasive tensiomyography. J Electromyogr Kinesiol. 2010;20(4):761-6.

21. Rodríguez-Matoso D, Rodríguez-Ruiz D, Sarmiento S, Vaamonde D, da Silva-Grigoletto ME, García-Manso $J M$. Reproducibility of muscle response measurements using tensiomyography in a range of positions. Rev Andal Med Deporte. 2010;3(3):81-86.

22. Rodríguez-Ruiz D, Rodríguez-Matoso D, Quiroga ME, Sarmiento S, García-Manso JM, da Silva Grigoletto ME. Study of mechanical characteristics of the knee extensor and flexor musculature of volleyball players. Eu J Sport Sci. 2012;12(5):399-407.

23. Simunič B. Between-day reliability of a method for non-invasive estimation of muscle composition. J Electromyogr Kinesiol. 2012;22(4):527-30.

24. Thomas JR, Nelson JK, Silverman SJ. Research methods in physical activity. $5^{\text {th }}$. ed. Champaign, IL: Human Kinetics; 2005

25. Westerblad $\mathrm{H}$, Allen DG. The influence of intracellular $\mathrm{pH}$ on contraction, relaxation and [Ca2+]i in intact single fibres from mouse muscle. J Physiol. 1993;466:611-28.

26. Westerblad H, Lännergren J, Allen DG. Slowed relaxation in fatigued skeletal muscle fibers of Xenopus and Mouse. Contribution of [Ca2+]i and cross-bridges. J Gen Physiol. 1997;109(3):385-99.

27. Westerblad H, Lee JA, Lännergren J, Allen DG. Cellular mechanisms of fatigue in skeletal muscle. Am J Physiol. 1991;261(2 Pt 1):C195-209.

28. Rodríguez-Ruiz D, Quiroga ME, Rodríquez-Matoso D, Sarmiento S, Losa J, de Saá Y, et al. The tensiomyography used for evaluating high level beach volleyball players. Rev Bras Med Esporte. 2012;18(2):95-9.

29. Leffler CT. Effect of ambient temperature on the risk of decompression sickness in surface decompression divers. Aviat Space Environ Med. 2001;72(5):477-83.

30. García-Manso JM, Rodríguez-Matoso D, Rodríguez-Ruiz D, Sarmiento S, de Saa Y, Calderón J. Effect of cold-water immersion on skeletal muscle contractiles properties in soccer players. Am J Phys Med Rehabil. 2011;90(5):356-63. 